\title{
THE INFLUENCE OF SME EMPOWERMENT TOWARDS SUSTAINABILITY OF BATIK BUSINESS: A STUDY OF HANDMADE MANGROVE BATIK SME AT SURABAYA, INDONESIA
}

\author{
Pudjowati Juliani*, Suman Agus, Sakti Rachmad Kresna, Adi Putu Mahardika \\ Doctoral Program of Economic Sciences, University of Brawijaya, Indonesia \\ *E-mail: julianiubhara@gmail.com
}

\begin{abstract}
Main responsibility in development program is creating an empowered society or creating society possessing energy, power or skill. The power is exhibited through physical, material, economic, institutional, cooperation, intellectual power and collective commitment aspect in implementing SME empowering principals. The business unit included in Micro, Small and Medium Enterprise (SME) is the breath of regional and national economy. Related to the matter, it is necessary to study SME empowerment by employing case study method. Research object is Mangrove Batik SME, Surabaya. The empowerment in batik small enterprise has been done by leagues/institutions through advising and developing in Surabaya, East Java has not been able to increase its competitiveness. The study aims to examine and analyze the influence of SME empowerment towards business sustainability. The object of the study is the businessman of mangrove batik in East Surabaya. The locations of the study are Kedung Baruk, Wonorejo, and Gunung Anyar areas. Total population and sample of all respondents are 58 mangrove batik businessmen. Data analysis method employed in the study is PLS (Partial Least Square) by using SmartPLS 2.0 program. The result of the study shows that SME empowerment significantly influences the business sustainability of mangrove batik businessmen in Surabaya city.
\end{abstract}

\section{KEY WORDS}

SME empowerment, business, sustainability, handmade mangrove batik.

Geographically, Indonesia is an archipelago country possessing basic in developing extractive sectors such as agriculture, plantation, fishery and poultry. It is related to the development program which aim is shaping individual and society to become independent. The independence includes independent in thinking, acting and controlling their desire. Small-Medium Enterprise (SME) sector is a string of business in the middle of economic crisis. Currently, about $99 \%$ the majority of business actors are SME businessmen which continuously grow significantly. Hence, SME becomes business sector which is able to become the support of stability of the national economy. The government could support SMEs by implementing various innovations to increase performance thus enable them to produce highly competitive products. Sulistiyani (2004) explains that etymologically empowerment originally comes from roots "power" means energy or ability. Considering the explanation, thus empowerment is meant as a process for receiving energy, power or ability, and or process of giving energy, power or ability from a party which has power to a party which has less or no power yet.

According to Winarni (2006), originally, small business is characterized as: (1) Usually in from of individual business and has not been in form of company firm, (2) Legal aspect of the business is weak, (3) Organizational structure is simple and task dividing is not in standard, (4) Most of the businesses have no financial report and do not separate personal's wealth and company wealth, (5) Management quality is low and it is rare to have business plan, (6) Main source of capital is personal capital, (7) Human resources are limited, (7) Owner has strong personal bound with the company, thus all duties of company have also become duties of the owner. Based on data from Statistics Indonesia (BPS) (2013), the population of small-medium enterprises (SME) was 42.5 million units or $99.9 \%$ of total national business actors. SME gives a significant contribution towards employees' hiring as 
much as 99.6 percent. Meanwhile, SME contribution towards Gross Domestic Product (GDP) is 56.7 percent. Nevertheless, SME classic problems are a general obstacle which becomes basic causes. Limited access towards productive sources is mainly caused by difficulty in accessing capital from formal financial sources, lack of technology acquisition resulting in low productivity and low quality products, limited raw material and quality of human resources which have not been able to meet requirement whether in the form of formal education side or knowledge and skill, low rate of partnership structure with big companies, unclear product standardization to meets customers' desire, low product quality control, lack of export knowledge, and limited marketing network. The success of enterprise sector business becomes the contributor of Gross Regional Domestic Product (GRDP) in economic growth. GRDP is strongly influenced by three elements such as government as policy and strategy maker, conducive market, and reaction or response of business actors (Sudantoko, 2010).

In the last five years, the structure of Gross Regional Domestic Product (GRDP) Surabaya develops in each sector dominated by commerce, hotel, and restaurant as well as manufacturing industries. This conditions encourages every economic sectors, which in turn, encourages small medium enterprises businesses development in East Java especially in Surabaya city. Another SME weakness is lack of information access, especially market information (Ishak, 2005). It becomes an obstacle in distributing products since limited access to market information will cause low market orientation and competitiveness at the global level. The empowerment in small batik industries especially Handmade Batik Mangrove SME which has been done by leagues/institutions through advising and developing in Surabaya, East Java, has not been fully able to increase the competitiveness. But government effort in supporting handmade mangrove batik SME is done by empowering SME of each sub-district to the district level and synergizes with other government institutions to increase income. The existence of business actors as well as owners and crafter of handmade mangrove batik, generally the influence of role model (patron) has relationship pattern which has positive, negative even original which encourages in creating an asymmetric relationship (Legg,199 in Nuryadin,2010). Thus by creating the way of empowering economy through handmade mangrove batik SME businessmen is able to achieve sustainability and survive in the business. Pranarka and Vidhyandika (1996) explain that the process of empowering contains two tendencies. First, the process of empowering which emphasizes the process of giving or diverting some power, dominance to society in order to empower an individual. In the current era of reformation and decentralization, demand towards empowering players who have sufficient ability becomes stronger. Businessmen of handmade mangrove batik SME as business owners feel that empowerment is not only demanded to enrich knowledge, but it also demanded to increase skill in designing empowerment program for SME. The success of SME empowerment will be realized if all stakeholders together have role according to their responsibilities whether as a regulator which includes regional government, SME business actors, thus success and advancement of SME will be soon implemented. Based on the background and descriptions above, it is important and beneficial to analyze whether SME empowerment significantly influences the sustainability of mangrove batik business in Surabaya city.

\section{LITERATURE REVIEW}

The ability of SME empowerment actors is ability expected to be able to empower society. The ability of the empowerment actors is measured by three aspects, they are: (a) knowledge/cognitive, (b) attitude/effective and (c) skill/psychomotor. The process of empowerment is a cycle or process in involving society to corporate informal groups or nonformal groups to investigate problems, plan, implement and evaluate towards the program which has been planned together. The process of empowerment is measured through (a) quality and quantity of society involvement starting from investigating or analyzing problems event, (b) program planning, (c) program implementation, and (d) involvement in evaluation continuously. (Widjajanti, 2011). The purpose of empowerment is to increase the power of weak and unfortunate people (Ife, 1995:56) 
Aristoteles' thought in economic development is related to prosperity, stating that income and wealth are not final purposes but as devices to get other purposes in inventing new innovation in "Capability" approach (Sen, 1999) in Todaro and Smith (2011: 22-23) which means that capability to function has role to decide wealth or not a person's status. The capability becomes freedom owned by a person related to the choice of function which depends on the person's personal traits (the change of personal traits becomes function or pace in society) and level of the control for certain commodity. Sen states that economic growth should not be viewed as purpose. Development should pay more attention to the effort of increasing life quality. The condition is possible to involve society in a form or participation which makes community-based on economic development appears (Gitosaputro and Kordiyana, 2015) whether in the process or in utilizing the result which is still discriminated only for current groups of capital owners.

Mardikanto(2013) stated that development without prioritizing society's active role will cause society empowerment losing its soul and trapped in social engineering. It places society only as an interest supportive object, whether it is for government bureaucracy, society social leagues, or other donors which take society name for their personal or their groups purposes. Garna (1997) in Zainuddin (2014) depicts generally the existence of relationships between development and industrialization, they are 1) the used material for industrialization and development process is in one line event to increase prosperity, 2) industrial development as effort of increasing quality of human resources and ability in utilizing natural sources, 3) industrial development will trigger and mutually relates to development in other sectors which can broaden job vacancies which are expected will increase income and buying power of society, and 4) imbalance will occur in economic development which is harmful economically or non-economically. According to Santoso (2009) in order for small-medium business realize independent regional economic development, it requires all parties possessing interests (stakeholders)or all society elements (government, businessmen, universities as well as society and society leagues) to be involved in planning, implementing, executing, controlling, monitoring, and evaluating. Al Teszler in Firtriati (2015) explains that the effort of empowering SME should be seen as something internalized in the whole process of economic development. In the context of regional development, Husaeni (2011) views the internalization effort can be facilitated through formulating policy process which is done by Development Planning Agency at Sub-National Level. Huseini (2011) states that regional are developed based on the main competitiveness it is not based on their most reliable export products which had been done at this time. The thought is based on the condition that not all regionals have excellent natural sources. Hayter (2000) states that SME adds multiplier effect which will create connection/relation. Small industry is an activity conducted in society homes whose workers are family members, neighbors without bounding to time and workplace (Tambunan, 2010).

Society empowerment (Slamet:2000) in Theresia et.al (2014) is defined as development advising process which Mardikanto(2010) defines as: "Social, economic and political change process to empower and strengthen society ability through togetherness which is participative, in order to change attitude towards all stakeholders themselves (individual, groups, institutions). These stakeholders are involved in the development process for the sake of more empowered, independent and participative life which becomes more prosperous continuously." Paul (1987) in Priyono and Pranarka (1996) states that empowerment means fair power dividing in order to increase political and power awareness in groups which are assumed to have a low ability as well as widening influencing power towards process and its development result. Khan (1997:44) in Purnama (2007:92) states that empowerment is a tie in the relation among personnel which is continuous in developing trust between society and government.

According to Foster in Darsono and Ashari (2005: 101), bankruptcy an obstacle which exhibits the existence of terrible liquidity problems which cannot be solved unless through rearranging company's structure and operation. Bankruptcy usually defines as a failure of the company in running its company operation to make a profit. According to Hanafi and Halim (2003: 261), information related to the prediction of business sustainability is important for 
parties which are related such as loan givers, investors, government, accountants, and management.

\section{CONCEPTUAL FRAMEWORK OF THE STUDY}

The present study focuses on the variable of SME empowerment as well as its level of influence towards variable of business sustainability. The writer is interested in analyzing the level of relation between each variable based on the existed condition on mangrove batik SME industry in East Surabaya city, as its sales production has not been absorbed by market optimally.

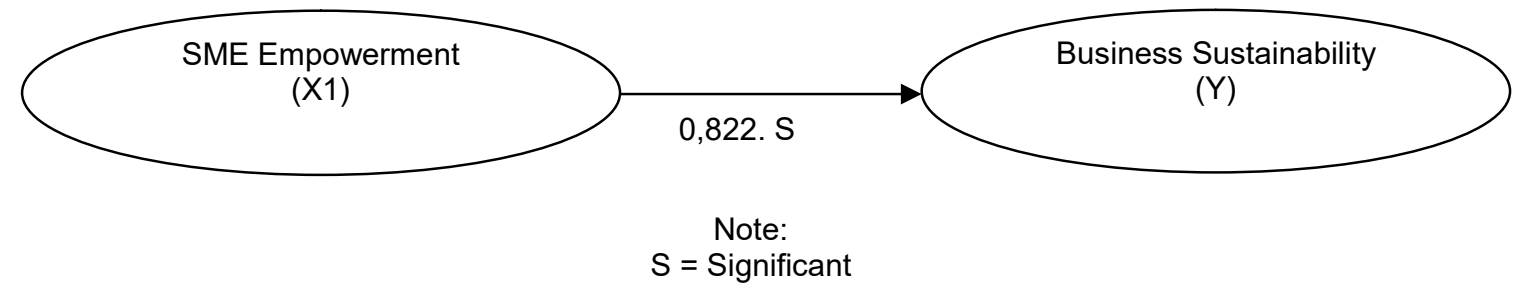

Hypotheses of the Study:

The Influence of SME Empowerment towards Business Sustainability. Government involvement in empowering SME is regulated clearly in Act No. 20 in 2008 about SME. The Act contains general regulation, foundation, principals and empowerment objectives, criteria, creating a business condition, business development, funding and guarantee, partnership, empowerment coordination, administrative sanction, and criminal determination. In order to empower SME, the involvement of stakeholders strongly decides the success. Joshua Abor and Peter Quartey study (2010) discuss characteristics, a contribution of SME towards economic growth and its obstacles to SME growth in developing countries especially in Ghana and South Africa. In the study, it is revealed that SME I Ghana and South Africa have many similarities in terms of characteristics and their economic roles. But two things make them different, in terms of capacity and regulation. In empowering SME, the obstacle is factors such as lack of access to precise technology, limited access to international market, the existence of Act and regulation which obstructs the sector, low capacity of the institution and lack of skills and management training, and financial access is a major problem for SME. It also occurs in a study conducted by Ni Putu Eka Lestari (2014) entitled Empowerment Strategy of SME Crafted Woods in Bali which analyzes chain value of the crafted wood industry in Gianyar, Bali. The study analyzed industry of crafted wood Gianyar, Bali strategic position. In the result of chain value, there are still numerous lacks of raw material supply from Bali Island. Meanwhile, in downstream, lack of support from government becomes an obstacle in distributing products. In an analysis of SWOT, the result of mapping in quadrant II indicates that strategy increases the ability and investment to increase quality and capacity of production in order to achieve efficiency. The result of AHP was obtained which revealed that marketing process becomes priority factor which decides prospects of crafted woods in Gianyar, Bali. Based on the explanation above, it is assumed that SME empowerment has an influence towards business sustainability thus proposed hypothesis was:

$\mathrm{H}_{1}$ : The increase of SME empowerment can increase business sustainability more.

Operational Definition:

SME Empowerment. SME empowerment is an effort to actualize potential which has already been owned by the SME itself. Therefore, the main of the approach of SME empowerment is emphasizing the importance of independent SME as a self-organized system. The approach of SME empowerment is expected to be able to give the role to the individual (Singarimbun.1989:46) UU No.20 Year 2008):

- Funding;

- Media and infrastructure;

- Business information; 
- Partnership;

- Business legalization;

- Business opportunity;

- Institution support.

Business Sustainability. Business sustainability is a condition where companies/industries/business actors are still able to run in defending their business operational including are able to increase their business profit achievement, develop and maintain sources for future needs (Olson et.al, 2003 in Utami, 2007). According to Ali Hasan (2008:239) and Kurniasari (2011), realization is real action or existence of movement/change from already made or implemented plan:

- Availability of raw material;

- Availability of capital;

- Human resource development;

- Product innovation;

- Promotion necessity;

- Customer demand.

\title{
METHODS OF RESEARCH
}

The study is an explanatory study which is meant to give an explanation of the causal relationship between variables through hypothesis examination as well as elaborate. The study employed quantitative approach. Locations of the study are in Kedung Baruk, Wonorejo, and Gunung Anyarin East Surabaya city. The study was done in 6 months. The analysis method of the study employed is PLS (Partial Least Square) by using SmartPLS 2.0 M3 program. (Ghozaliand Latan, 2012:18). The total sample is 58 respondents of mangrove batik businessmen.

\section{RESULTS AND DISCUSSION}

Recapitulation of the Study Result:

\author{
Influence between Variable \\ SME Empowerment->Business Sustainability
}

\author{
Coefficient Path \\ 0.822
}
T- Statistic 5.579
$P$-Value 0.000

Note Significant

$\mathrm{H}_{1}$ : The Influence of SME towards Business Sustainability.

A score of the correlation coefficient is 0.822 whose mark is positive and its t-statistic score is $5.579>1.960$ or value $0.000<0.05$ indicating that the result of analysis between SME empowerment with business sustainability is proven to have a positive correlation and it significantly has influence. It means a higher score of SME empowerment will be able to increase business sustainability. Therefore the hypothesis proposed in the study is able to be accepted and it is supported by empirical fact. The result of the study gives a meaning that SME empowerment in business actors or owners of handmade mangrove batik is measured from funding, media, and infrastructure, business information, partnership, business legalization, business opportunity, as well as institutions, support directly give influence towards business sustainability. The result of the study is in line with a study by Joshua Abor, Peter Quartey (2010), which discusses characteristics and SME contribution towards economic growth as well as its obstacles for SME growth in developing countries especially in Ghana and South Africa. It revealed that SME in Ghana and South Africa have many similarities in terms of characteristics and their economical roles. But the differing factor is in terms of capacity and regulation. Empowerment is a process in where people become sufficiently strong to participate, divide monitoring and to influence occurrences as well as leagues which influence their life. Empowerment emphasizes on people to acquire skill, knowledge and adequate power to influence their life and other people life which becomes their attention (Parsons, et al., 1994:106) Main purpose of development implemented by the government is to increase the living standard of society. Various businesses from various 
sectors are continuously developed as an effort to achieve the purpose. But occasionally, failure occurs in its implementation, such as uneven distribution of implementation, especially in society. It occurs because the main approach in development is implemented by marginal society and rural society. The development planning possessed top down planning trait.

Sabirin(2001) explains that to empower society of low or small business group could be conducted by providing an affordable business funding source. One of the strategies of funding for this group is microcredit business. The micro-funding institution is an institution which provides financial services to society with low income and it includes the poor group. The micro financial institution has specific trait since it relates funding demand of poor society with fund availability. Product design of mangrove batik in East Surabaya city is one of image forming aspects. The company is also more aware of the importance of marketing value of product design, especially its appearance design.

Limitation of the Study. The study was done limitedly on handmade mangrove batik businessmen in Surabaya city thus the result of the study cannot be generalized since the result would be different if it was done on the different object.

\section{CONCLUSION}

SME empowerment of mangrove batik businessmen in East Surabaya city are able to produce batik products innovatively based on model development in the market. The finding provides the solution in the form of businessmen or owners of handmade mangrove batik skill in empowerment role will be effective to be able to increase society empowerment independently supported by capital information and raw material source, support of media and infrastructure, if society previously increases its empowerment.

Businessmen of mangrove batik in Surabaya already have the proactive attitude towards smoothness of process and have good feedback towards products of mangrove batik in the future thus they can anticipate the continuity of production. Continuous business is a business which is able to produce whether it is based on order and or is able to sell the products to market continuously with all existing limitation.

\section{SUGGESTIONS}

In order to increase the empowerment, SME society is not adequate enough to develop merely physical capital, but it should increase the quality of human resources as success requirement in doing empowerment with similar SME partners. In this reformation era, society should be able to take a decision in conducting new business for the future.

SME necessarily needs to be given support in form of technology/precise tools to encounter the problem of the unmatched amount of production caused by weather factor and SME limitation in production activity obstacles.

\section{REFERENCES}

1. Abor, Joshua., Peter Quartley. 2010. Issue in SME Development in Ghana and Shouth Africa. International Research Journal of Finance and Economics. Http: //www.eurojournal.com/finance.com/finance.htm

2. Darsono dan Ashari.2005. Pedoman Praktis Memahami Laporan Keuangan. Salemba Empat. Jakarta.

3. Fitriati, Rochma. 2015. Menguak Daya Saing UMKM Industri Kreatif: Sebuah Riset Tindakan Berbasis Soft Systems Methodology. Edisi Pertama. Yayasan Pustaka Obor Indonesia. Jakarta.

4. Ghozali, Imam dan Hengki Latan. 2012. Smart Partial Least Square 2.0. Badan Penerbit Universitas Diponegoro. Semarang.

5. Gitosaputro, Sumaryo dan Kordiyana K.Rangga. 2015. Pengembangan dan Pemberdayaan Masyarakat: Konsep, Teori dan Aplikasinya di Era Otonomi Daerah. Cetakan I. Graha IImu. Yogjakarta. 
6. Hasan, Ali. 2008. Manajemen Pemasaran dan Marketing. Alfabeta. Bandung.

7. Hayter, Roger.2000. The Dinamic of Industrial Location: The Factory, The Firm, and the Production System. John Wiley and Sons.Chichester. Http: books.google.com

8. Husaini, Martini. 2011. Memperkuat Daya Saing Daerah. Seminar of Local Governance Watch. Faculty of Social and Political Sciences, University of Indonesia, Depok. Jakarta.

9. Ife, James, William. 1995. Community Development: Creating Community AlternativesVision.Analysis and Practice. Longman. Mebourne. Australia.

10. Kurniasari, 2011. Pengaruh Faktor-faktor Keberdayaan Produsen Tahu Terhadap Keberlanjutan Usaha Terkait Dengan Faktor Lokasi Di Kota Kediri. https://eprints.uns.ac.id/10126/

11. Lestari, Ni Putu Nina, Eka. 2014. Desertasi: Strategi Pemberdayaan Industri Kecil Kerajinan Ukiran Kayu di Kabupaten Gianyar Propinsi Bali. Universitas Udayana Denpasar. Diterbitkan.

12. Mardikanto, Totok dan Soebianto, Poerwoko. 2013. Pemberdayaan Masyarakat dalam Perspektif Kebijakan Publik. Alfabeta. Bandung.

13. Nuryadin, La Ode, Taufik. 2010. Desertasi: Studi Kapital Social Komunitas Suku Bajo (Studi Kasus Komunitas Suku Bajo di Pulau Baliara Propinsi Sulawesi Tenggara). Universityof Indonesia Jakarta.Unpublished

14. Parsons, Ruth, J., James, J. \& Santos, H. H., 1994. The Integration of Social Work Practice. California: Wadsworth Inc.

15. Purnama, Chamdan. 2007. Desertasi: Analisis Pengaruh Pemberdayaan yang Dilakukan Pemerintah Terhadap Keberhasilan Usaha Industri Sandang di Propinsi JawaTimur. University of Brawijaya Malang. Unpublished

16. Pranarka, A.M.W. dan Vidyandika,. 1996. Dalam Priyono, O.S dan Pranarka, A.M.W. 1996. Pemberdayaan: Konsep Kebijakan dan Implementasi. Penerbit: Centre for Strategic and International Studies. Jakarta.

17. Sabirin, S. 2001. Pemanfaatan Kredit Mikro untuk Mendorong Pertumbuhan Ekonomi Rakyat di Dalam Era Otoda. Orasi IImiah Lustrum IX. Universitas Andalas, Padang, 13 September. Diakses 5/9/2016.

18. Santoso, 2009. Analisis Pengembangan Usaha Mikro Kecil, Menengah.

19. untuk Mengetahui Pertumbuhan Ekonomi Sebagai Upaya Penegentasan Kemiskinan dan Pengangguran Daerah Ngawi. Article retrieved on 5-7-2016. Https://media.neliti.com/media/publications/13885-ID analisis pengembangan usaha mikro kecil menengah untuk meningkatkan pertumbuhan.pdf

20. Singarimbun, Masri. 1989. Metode Penelitian Survei. LP3ES. Jakarta.

21. Sudantoko, Djoko. 2010. Desertasi: Pemberdayaan Industri Batik Skala Kecil Studi Industri Batik Kecil di Jawa Tengah. University of Diponegoro Semarang.Published.

22. Sulistiyani, Ambar Teguh. (2004). Kemitraandan Model-Model Pemberdayaan. Yogyakarta: IKAPI. Tambunan, Tulus. 2010. Perkembangan UKM di Indonesia: Suatu Tinjauan Teoritis dan Empirirs terhadap Pertumbuhan Unit Usaha Baru.Infokop.No.29. Tahun XXII.1-27.

23. Theresia, Aprilia et.al. 2014. Pembangunan Berbasis Masyarakat. Alfabeta. Bandung.

24. Todaro, Michael P, Todarodan Stephen, C, Smith. 2011. Pembangunan Ekonomi. Edisi II. Jilid 1.Penerbit Erlangga. Jakarta.

25. Utami, H.M.2007. Desertasi: Keberdayaan, Kemajuan dan Keberlanjutan Usaha Pengrajin: Kasus Kabupaten Sidoarjo dan Kabupaten Magetan Propinsi Jawa Timur.Master Program of Agricultural University of Bogor.Bogor.Published.

26. Widjajanti, Kessi. 2011. Model Pemberdayaan Masyarakat. Journal Ekonomi Pembangunan. Vol.2 No.1. P. 15-27. Https: //meia.neliti.com/media.../pdf

27. Winarni, Endang, Sri. 2006. Strategi Pengembangan Usaha Kecil Melalui Peningkatan Aksesibilitas Kredit Perbankan. Infokop. No. 29. Tahun.XXII.

28. Zainuddin, Rahman. 2014. Desertasi: Strategi Pemberdayaan USaha Mikro Kecil dan Menengah Serta Dampaknya Terhadap Pendapatan (Studi Kasus Pada Industri Mebel di Sulawesi Selatan). 